\title{
Single and Hybrid Nanofluids to Enhance Performance of Flat Plate Solar Collectors: Application and Obstacles
}

\author{
Qudama Al-Yasiri1', ${ }^{1}$ Márta Szabó1*, Müslüm Arıcl ${ }^{3}$ \\ 1 Department of Building Services and Environmental Engineering, Szent István University, H-2100 Gödöllő, 1 Páter Károly utca, \\ Hungary \\ 2 Department of Mechanical Engineering, Faculty of Engineering, University of Misan, 62001 Al Amarah City, Misan Province, Iraq \\ ${ }^{3}$ Department of Mechanical Engineering, Faculty of Engineering, Kocaeli University, 41001 Izmit/Kocaeli, 9 Sanayi, Turkey \\ *Corresponding author, e-mail: szabo.marta@szie.hu
}

Received: 07 October 2020, Accepted: 28 October 2020, Published online: 21 December 2020

\begin{abstract}
Solar energy represents the best alternative for traditional energy sources used in many thermal energy systems. Among solar thermal systems, Flat Plate Solar Collectors (FPSCs) are the most utilized type implemented in low and medium-level thermal domestic applications. Recently, the usage of nanofluids (NFs) to enhance FPSCs is one of the newest technologies that has drawn the attention of researchers to improve the overall thermal efficiency of solar systems. This paper briefly reviews the recent studies carried on thermal performance enhancement of FPSCs by implementing NFs (single and hybrid NFs) considering the main influential parameters such as particle concentration, particle size, and collector area. Finally, the main obstacles reported by the researchers such as the instability, viscosity, concentration limit, corrosion effect and others are identified, which is believed to be useful for interested newcomers in this research area. Based on the studies investigated in this paper, NFs, even under low concentrations, can remarkably improve the energetic and exergetic efficiency of FPSCs.
\end{abstract}

Keywords

nanofluid, hybrid nanofluid, Flat Plate Solar Collector (FPSC), thermal efficiency, solar energy

\section{Introduction}

Flat Plate Solar Collector (FPSC) is a popular type of solar collectors used in solar thermal applications. It is widely used in solar heating, cooling and domestic hot water applications [1-3]. Despite the simple-construction and low initial cost compared with other types, FPSC practically has low thermal efficiency and outlet temperature since the first development by Hottel and Whillier in the 1950s [4]. The water or air is usually employed as a heat transfer working fluid in FPSCs. The water-based collector has higher energetic and exergetic thermal performance compared with air-based collectors. Therefore, they are used in many applications. The typical FPSC comprises from glass cover, absorbing layer, fluid heat exchanger tubes, insulation layer and a frame, as shown in Fig. 1. The beam solar radiation passes through the glass layer and is accumulated in the form of heat inside the collector. The dark absorbing layer traps the heat and minimizes the reflected radiation. The heat then is transported to the water through heat exchanger pipes which are in contact with the absorbing layer. The frame supports the layers and protects them from weather conditions.

Many improvements have been made to increase the thermal performance of FPSC by dealing with the material of collector layers, collector configuration, heat exchanger

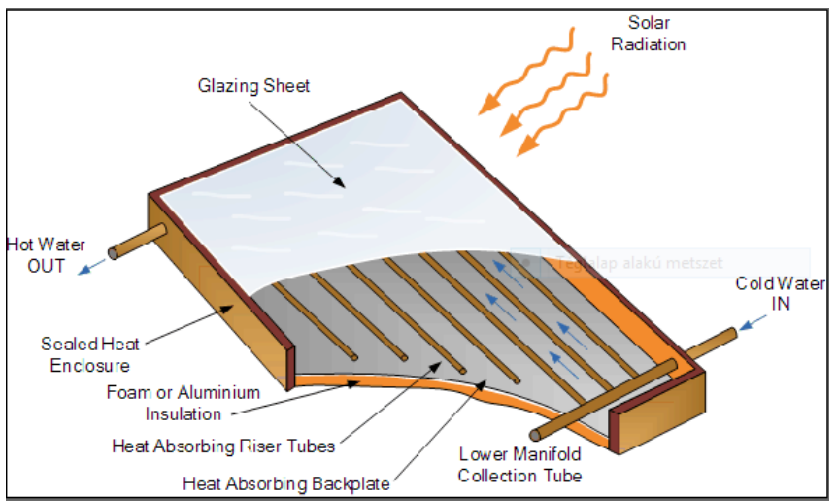

Fig. 1 Schematic of a typical FPSC. 
or the working fluid. Vettrivel and Mathiazhagan [5] replaced the single top glass layer of FPSC by double glass layers in order to reduce the heat transfer from the collector through the glass layer. The results revealed that the collector efficiency and outlet water temperature increased by $43 \%$ and $10-15{ }^{\circ} \mathrm{C}$, respectively compared with the single glass collector. Bhowmik and Amin [6] used reflectors to concentrate the direct and diffuse solar radiation towards FPSC. The reflectors were rotated in different angles to reflect as much as possible of sunlight. This technique improved the efficiency of FPSC by up to $10 \%$. Sakhaei and Valipour [7] coated the absorbing layer of three FPSCs by black paint, black chrome-coating, and carbon-coating to investigate the absorptivity of each collector. The results showed that the carbon-coating has the highest absorption rate because of the trapped sunlight and minimized reflection where the thermal efficiency increased by up to $69.4 \%$. Moreover, compared with the black-painted collector, the efficiency was increased by $13 \%$ and $11.3 \%$ using carbon-coating and black chrome-coating, respectively. Kim et al. [8] used coloured fluids to increase the absorptivity of the absorbing layer of FPSCs. They installed transparent tubes on the absorption layer of a traditional FPSC. Four coloured fluids (pure water, red, violet, and black) were flowed inside the transparent tube to investigate their absorptivity, which enhances the capability of absorbing layer. The study reported that the black fluid showed the best thermal performance, and up to $5 \%$ collector efficiency improvement was obtained. Fan et al. [9] introduced a new V-corrugated aluminum absorbing layer made with multi triangular channels to increase the optical and thermal performance of a conventional FPSC. The results showed that the optical and thermal efficiency of the new collector was improved by $15.8 \%$ and $10.8 \%$, respectively, over the traditional one. Further, the pumping power required to circulate the fluid of the new collector was reduced by about 4.1 times compared with that required for the traditional one. Various techniques have been proposed by researchers to improve the thermal performance of FPSC such as the arrangement of fluid heat exchanger pipes in a zig-zag manner [10], insertion of porous metal foam blocks [11], utilization of wire-coils and twisted-tapes [12], and recently, usage of nanofluids for overall heat transfer enhancement.

In the literature, there are thousands of published items each year dealing with the applications of NFs in different fields of heat transfer. Fig. 2 [13] shows the number of published items from the year 2015 to 2020 considering

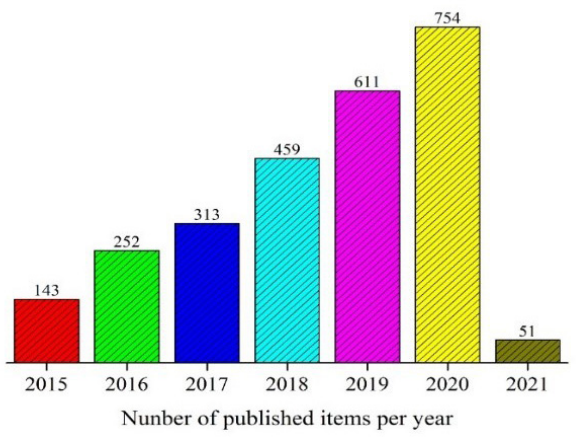

Fig. 2 Statistics of published items in Scopus database considering the keywords "nanofluids in flat plate solar collectors" [13].

the enhancement of FPSCs efficiency against the number of reviewed items in the current work.

In this paper, a review on the use of single and hybrid NFs in FPSCs in the recent research work has been presented and discussed. Different types of NF used in FPSCs were detailed, focusing on the thermal efficiency enhancement and considering the main affecting parameters such as particle size, particle concentration, and collector area. Moreover, a brief discussion on the main obstacles restricting the applicability of NFs based FPSC is also mentioned to highlight the necessary research works needed in future studies.

\section{Nanofluids}

\subsection{Overview of nanofluids}

The term nanofluid (NF) refers to the suspension of nanoparticles (NPs) with a size less than $100 \mathrm{~nm}$ into a base (host) fluid. This technology was presented for the first time by Maxwell [14]. NFs have proved an essential enhancement in the heat transfer of many thermal applications and showed excellent results in solar collector applications [15-17]. The most commonly used conventional fluids as a base fluid in NFs are dispersed water, ethylene glycol, a mixture of water and ethylene glycol and, engine oil and paraffin [18-21]. The types of NPs used to prepare NFs can be made from different materials, as listed in Table 1 [22]. These suspended NPs showed essential enhancement in the thermo-physical properties of the base fluid such as thermal conductivity, convective heat transfer coefficient, specific heat, and thermal diffusivity compared with the base fluid alone. Fig. 3 [23] shows the thermal conductivity range of different NPs and base fluids.

Different NP types are intensively studied by the researchers during the last years with much focus on the oxide ceramics in general, as shown in Fig. 4, $\mathrm{Al}_{2} \mathrm{O}_{3}$, for an instant, got the most attention among other NPs due 
Table 1 Type of materials used to synthesize NPs [22].

\begin{tabular}{ll}
\hline Material category & Examples \\
\hline Metals & $\mathrm{Cu}, \mathrm{Ag}, \mathrm{Au}, \mathrm{Fe}, \mathrm{Al}$ \\
Oxide ceramics & $\mathrm{Al}_{2} \mathrm{O}_{3}, \mathrm{CuO}$ \\
Nitride ceramics & $\mathrm{AlN}, \mathrm{SiN}$ \\
Carbide ceramics & $\mathrm{SiC}, \mathrm{TiC}$ \\
Semiconductors & $\mathrm{TiO}_{2}, \mathrm{SiC}$ \\
Carbon nanotubes and & ${\mathrm{Alloyed} \mathrm{NPs} \mathrm{such} \mathrm{as} \mathrm{Al}_{70} \mathrm{Cu}_{30} \text { and NP }}_{\text {composite materials }}^{\text {core-polymer shell composites }}$ \\
\hline
\end{tabular}

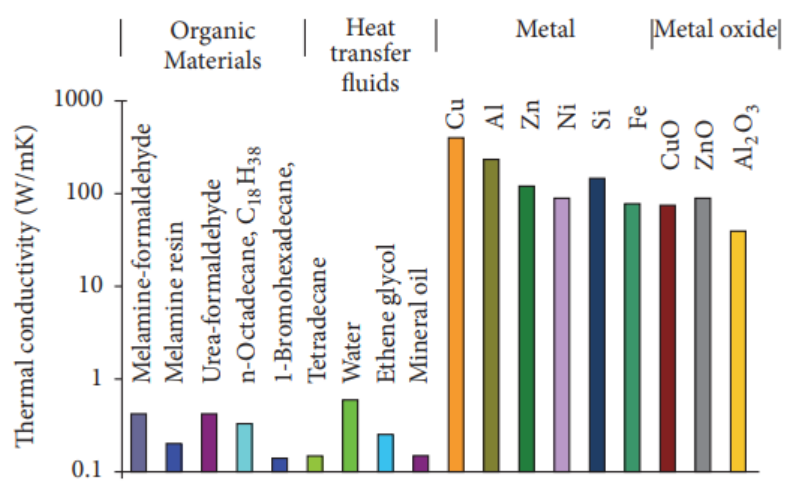

Fig. 3 Thermal conductivity of different NPs and base fluids [23].

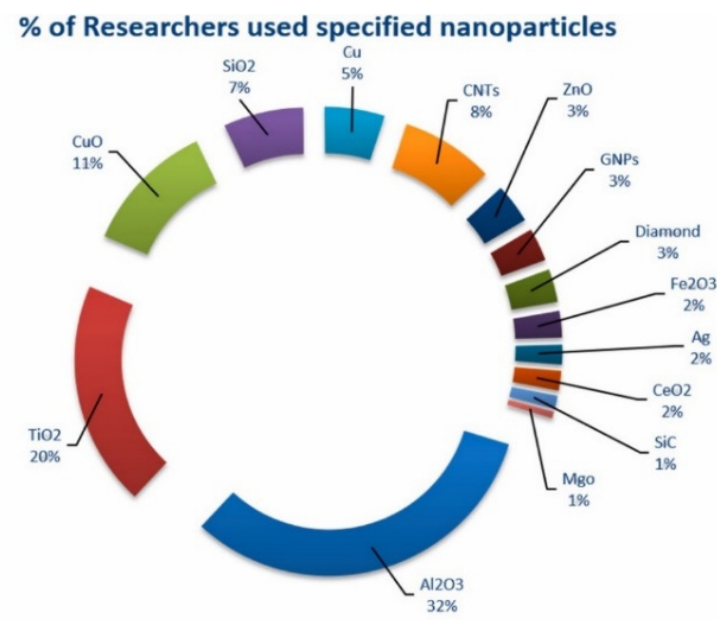

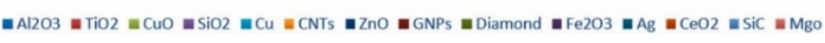

Fig. 4 Percentage of NP materials used in the literature studies [18].

to its wide availability, low cost, good stability with base fluids, high thermal conductivity, and other physical properties [24]. Further, many other materials are still not highlighted, mainly due to their high cost, which makes this area under research.

\subsection{Classification and preparation of NFs}

NFs are classified into two main categories: single material NF where a single kind of NP material is immersed into the base fluid, and the hybrid NF where more than one type of NPs are used to prepare the NF. The latter represented an advanced category and was introduced for the first time by Jana et al. [25] which showed better thermo-physical properties than the liquids with single NPs.

Preparation of NFs represents the first foot-step in the way of NF application. It can be done in single or two-steps method to get a homogenous fluid with neglected agglomeration for long-term operation and stable thermo-physical properties. In the single-step method, NPs can easily be prepared via physical vapour deposition technique or liquid chemical method. Therefore, the drying/storage/dispersion/ transportation processes are averted [26], which minimize the agglomeration. The main disadvantage of this method is that residues of reactants are left in the NF due to incomplete reaction or lack of stability which affects the purity of NF. Furthermore, only low-vapour pressure base fluids can be used in this method, which limits its application [26]. In the two-step method, NPs are produced by a chemical vapour deposition technique, inert gas condensation technique, etc. to produce powder NPs [27]. Then, the powder is mixed with the base fluid with the help of induction of intense magnetic force agitation, ultrasonic excitation, high shear mixing, ball milling and homogenization. The major disadvantage of this method is that due to the high surface area and surface gravity, NPs tend to agglomerate, which reduces the thermal conductivity of NF and affects its stability. In general, the single-step method is appropriate for small production, and the two-step method is cost-effective for mass production [28]. Moreover, the two-step method is optimal for tri-hybrid NFs (when three different NPs concentrations are mixed) to obtain a long time stable suspencion [29].

More details on this subject can be found in [30-32]. Many researchers highly recommend the two-steps method as it showed better characteristics of the prepared NFs as well as its economic advantage. Hybrid NFs possess a big challenge in preparation studies due to the use of more than one type of NPs (Fig. 5 [33]). Babar and Ali [22] discuss more detailed information about this aspect.

\subsection{Applications of NFs in solar systems}

Broadly, NFs have been showing essential enhancement in the overall thermal performance of many engineering systems. Focusing on solar applications, NFs positively improved the heat transfer of numerous systems other than FPSCs such as: Solar desalination systems [34], photovoltaic/thermal systems [35], solar heat exchangers [36], parabolic trough solar collectors [37], evacuated tube solar collectors [38], heat pipe in solar collectors [39], solar thermal energy storage systems [40], etc. 


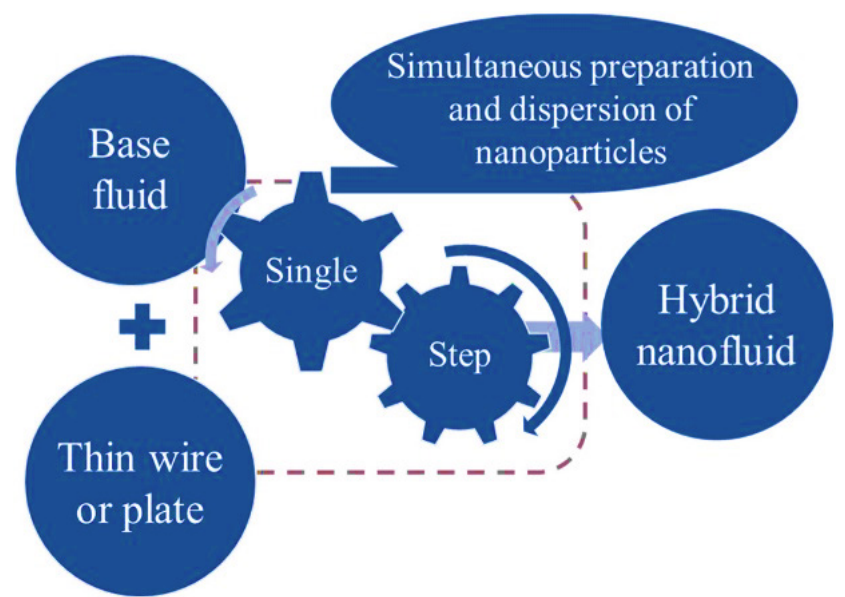

(a)

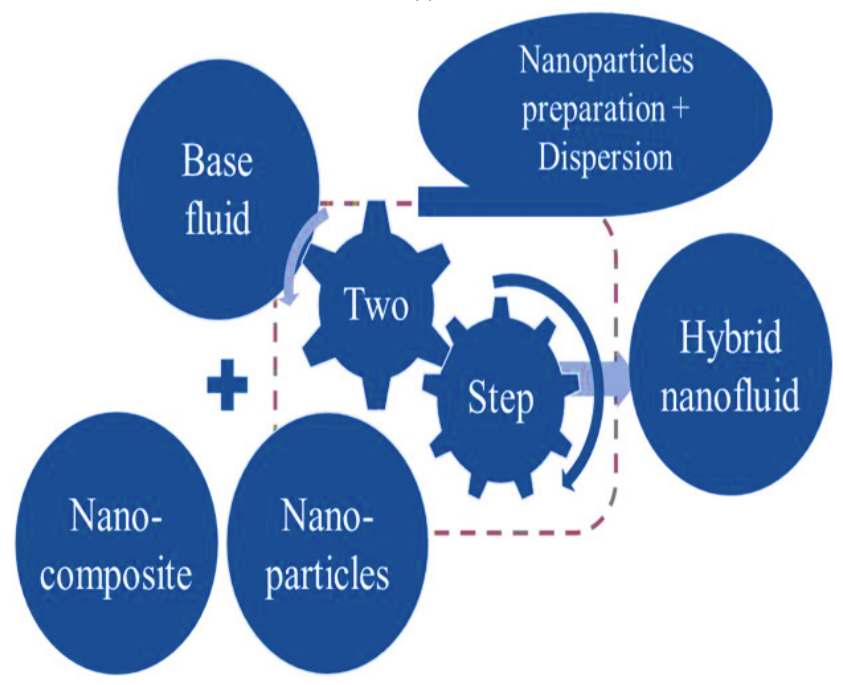

(b)

Fig. 5 Illustration of (a) single and (b) two-step methods [33].

The use of NFs in solar thermal systems results in many advantages, which can be summarized as follows:

- Technical considerations: NFs enhance fluid properties such as thermal conductivity, convective heat transfer coefficient and thermal diffusivity, which increases the heat transfer rate of the system thanks to the Brownian motion [41]. In FPSCs, the optical absorption of the fluid increases [42], the convective and radiative heat transfer losses will decrease as the heat transfer between the absorbing layer and heat exchanger increases. All in all, the overall thermal efficiency of the system improves remarkably.

- Economic considerations: Despite the initial and operational cost, with the use of NFs the area of the solar collector reduces, leading to a reduction in the collector cost. The size of FPSC can be reduced in different percentages depending on the type of NPs, as shown in Fig. 6 [43]. Furthermore, it has

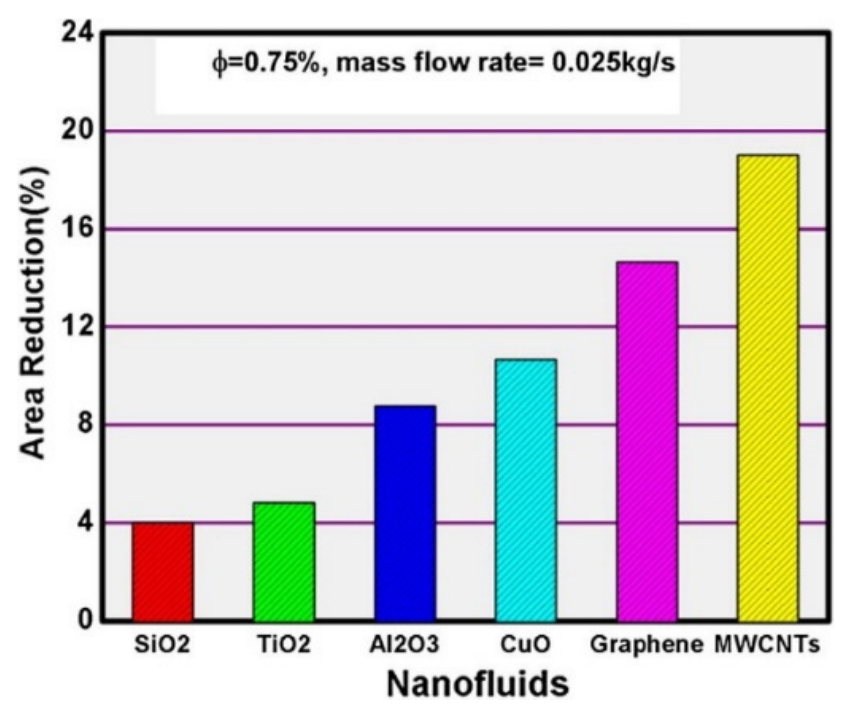

Fig. 6 Size reduction of FPSC using various NF types [43].

been reported that the use of hybrid NFs is cost-effective rather than single NFs thanks to their high potential of Thermal Conductivity Elevation (TCE) as illustrated in Fig. 7 [44].

- Environmental consideration: The increased efficiency of solar collector thanks to NFs cuts the $\mathrm{CO}_{2}$ emissions and decreases the reliance on traditional energy sources.

3 Application of NFs to enhance performance of FPSCs Many numerical and experimental studies discussed the potential of NFs to improve the efficiency/thermal performance of FPSCs. These studies reported the correlation of thermo-physical characteristics of the prepared NFs with the type of NPs and their concentration where most findings showed enhancement in the heat transfer

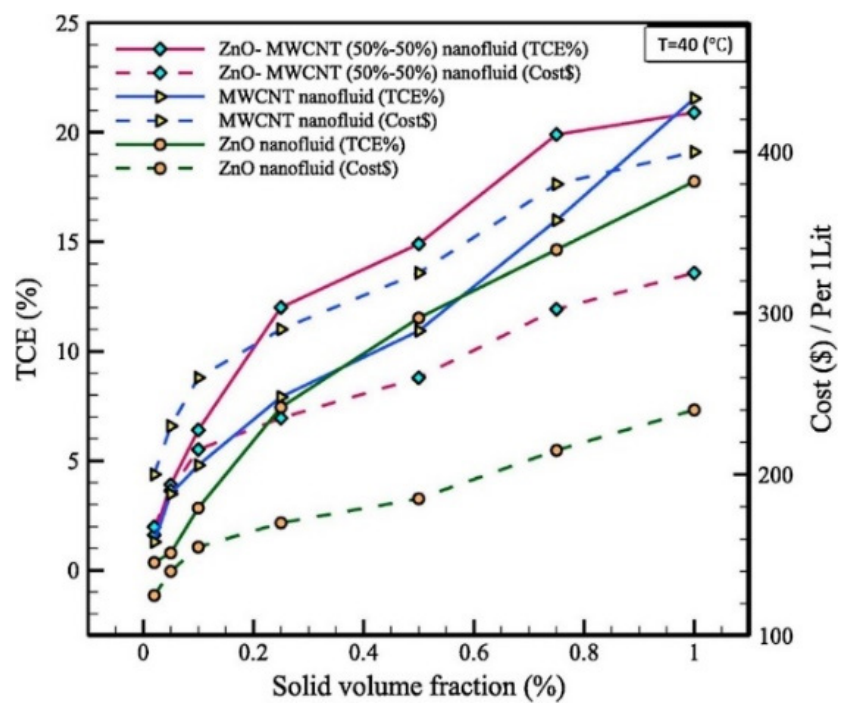

Fig. 7 Cost-effectiveness of hybrid NFs compared with single NFs [44]. 
coefficient, thermal conductivity, and optical absorptivity $[45,46]$. Furthermore, the efficiency of FPSC and thermophysical properties of new fluid will be changed remarkably depending mainly on the type of NPs dispersed and its concentration [47, 48]. For instance, Fig. 8 and Fig. 9 [49] show the improvements in fluid properties when single and hybrid NPs are used.

The experimental studies of NFs in FPSCs show a more realistic behaviour of NFs rather than numerical studies which the latter relies on engineering approximations. Verma et al. [50] illustrated the experimental methodology analysis that should be followed to study the optimal exploitation of NF for solar collectors, as shown in Fig. 10. All aspects of prepared NF (thermal conductivity, density, and viscosity) must be investigated in conjunction with the technical parameters of the solar collector (inlet and outlet temperature, collector inclination, ambient temperature) to study the optimal utilization of NF and its impact on the performance of solar collector.

Improvement of FPSC using NFs has been studied using various types of NPs with different concentrations. Hawwash et al. [51] numerically and experimentally investigated the enhancement of FPSC using Double Distilled Water (DDW) and alumina NF at six different concentrations ranging between $0.1-3 \%$. They conducted the study according to ASHRAE standard 86-93 under Egyptian climate conditions. The results showed that alumina NF could improve the collector thermal efficiency over the DDW by about $18 \%$ with a high-temperature difference. Furthermore, the numerical results obtained using ANSYS Fluent 17 software indicated that the increase of volume fraction of alumina NF until $0.5 \%$ increased the thermal efficiency of FPSC. However, a further increase in concentration inversely impacted the thermal performance

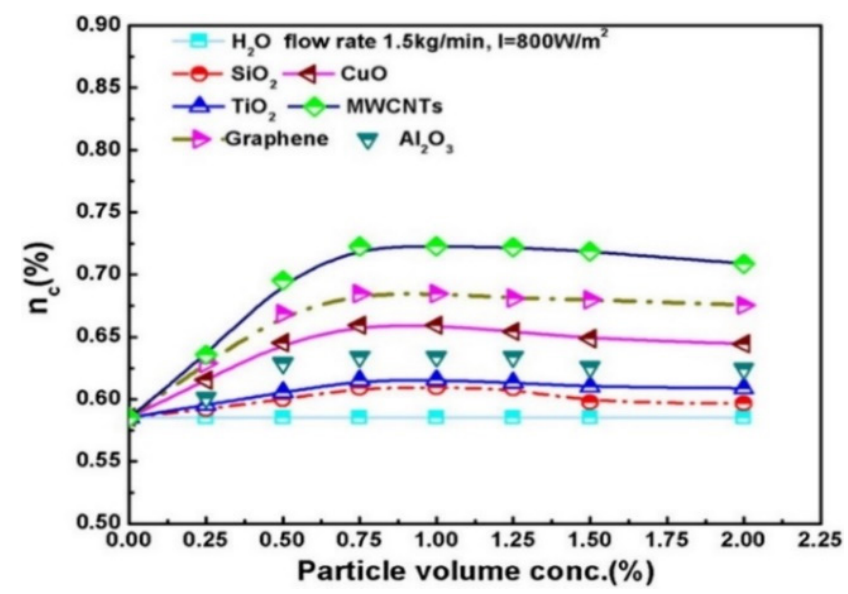

Fig. 8 FPSC efficiency $\left(n_{c}\right)$ versus concentration for different NPs [43].
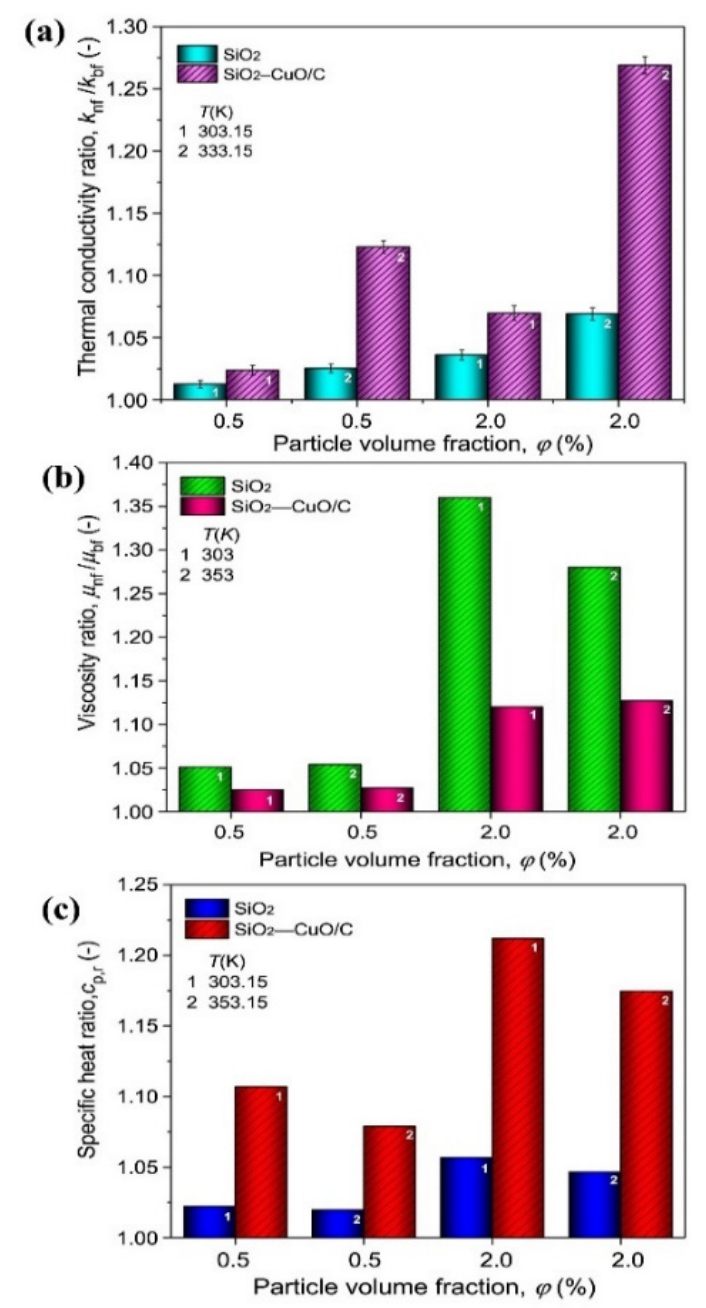

Fig. 9 Enhancements in thermophysical characteristics of single and hybrid NPs: (a) thermal conductivity, (b) viscosity, (c) specific heat [49].

due to increasing pressure drop. The effect of using $\mathrm{CeO}_{2}$ $(25 \mathrm{~nm})$-water as a NF to enhance the efficiency of FPSC was experimentally studied by Sharafeldin and Gróf [52] under Hungarian climate conditions. The volume fractions of NPs used in the experiment were $0.0167,0.0333$ and $0.0666 \%$ prepared with the sonication method and the NF studied with a pumping rate of $0.015,0.018$ and $0.019 \mathrm{~kg} / \mathrm{s} \mathrm{m}^{2}$. The results revealed that the maximum collector efficiency achieved was $10.74 \%$ at $0.666 \%$ volume fraction and $0.019 \mathrm{~kg} / \mathrm{s} \mathrm{m}^{2}$ mass flux rate which proved that the collector efficiency was directly proportional to the volume fraction and mass flux rate. Genc et al. [53] studied the enhancement of FPSC based $\mathrm{Al}_{2} \mathrm{O}_{3}$-water NF compared with the water as a working fluid. The heat transfer of NF was analyzed at 1,2 and $3 \%$ volume fraction and mass flow rate ranged between 0.004 and $0.06 \mathrm{~kg} / \mathrm{s}$ to investigate the thermo-physical properties under different Reynolds numbers. The results indicated that the highest collector thermal efficiency obtained 


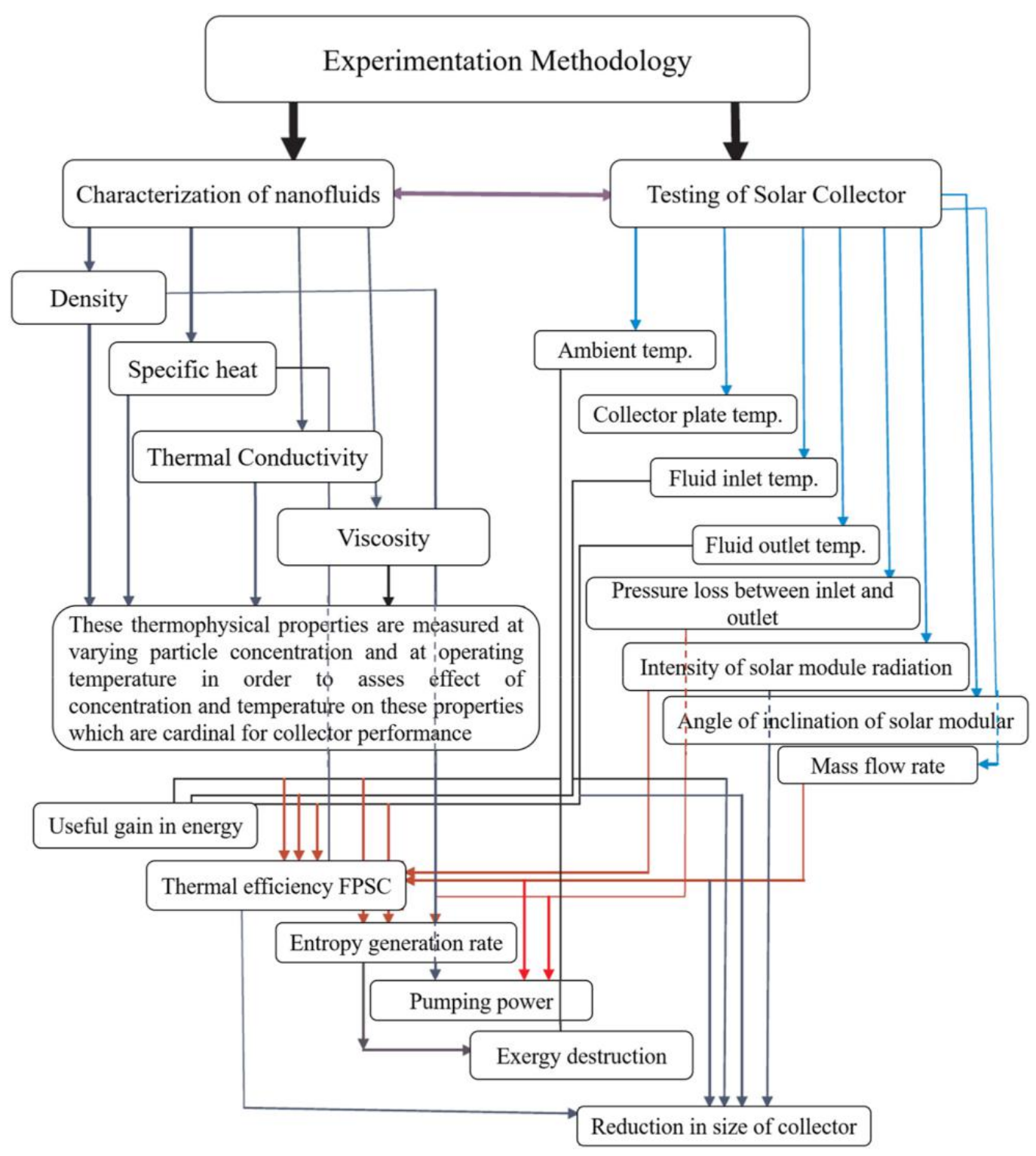

Fig. 10 Flowchart of investigating NFs in FPSC [50].

was $83.90 \%$ at $1 \%$ volume fraction and $0.06 \mathrm{~kg} / \mathrm{s}$ mass flow rate. Furthermore, an increment of collector outlet temperature by $7.20 \%$ achieved at $3 \%$ volume fraction and $0.004 \mathrm{~kg} / \mathrm{s}$ mass flow rate. The results also revealed that the efficiency of FPSC could increase using NF at a low flow rate and the base fluid can be an effective working fluid beyond the critical flow rate which was $0.016 \mathrm{~kg} / \mathrm{s}$ in their study. Performance improvement of FPSC using $\mathrm{TiO}_{2}$-water NF was experimentally investigated by Kiliç et al. [54]. They mixed $2 \%$ concentration of $\mathrm{TiO}_{2}$ NPs with $0.2 \%$ of Triton X-100 surfactant using the ultrasonic bath for $8 \mathrm{~h}$ to get stable NF and prevent the agglomeration during working time. The improvement of collector efficiency was estimated based on ISO 9806:2017 standard [55], where the highest instantaneous efficiency obtained was $48.67 \%$ and $36.20 \%$ for the NF and pure water fluid, respectively. Alawi et al. [56] experimentally investigated the thermal performance of FPSC using Pentaethylene Glycol treated Graphene nanoplatelets (GNPs)/water as a working fluid at $0.025,0.05,0.075$, and $0.1 \%$ concentrations. The experiment set with 303,313 , and $323 \mathrm{~K}$ collector inlet temperatures and $0.00833,0.01667$, and $0.025 \mathrm{~kg} / \mathrm{s}$ mass flow rates was exposed to 500,750 , and $1000 \mathrm{~W} / \mathrm{m}^{2}$ heat flux intensities. The results revealed that the thermal conductivity, viscosity and density were augmented as the concentration of NPs increases and the efficiency of FPSC was directly proportional to the flow rate and heat flux. Moreover, the efficiency of FPSC increased using NFs by $10.7 \%, 11.1 \%$, and $13.3 \%$ with the mentioned mass flow rates compared to the case where water was used as the working fluid. 
Hybrid NFs are the newest generation and advanced working fluids [57], which showed good improvements on the thermo-physical properties of different solar thermal applications over the single NFs [58]. The literature has limited studies regarding the use of hybrid NFs for FPSC as this trend is still under research. Babu et al. [59] analytically investigated the enhancement of FPSC using $\mathrm{Cu}-\mathrm{CuO} / \mathrm{H}_{2} \mathrm{O}$ hybrid $\mathrm{NF}$ and compared with $\mathrm{Cu} / \mathrm{H}_{2} \mathrm{O}$ and $\mathrm{CuO} / \mathrm{H}_{2} \mathrm{O} \mathrm{NFs}$ in terms of energetic and exergetic performance of the collector. The hybrid NF showed higher thermo-physical properties over the single NFs under different flow rates and concentrations. Findings showed the enhancement in the thermal conductivity of $\mathrm{Cu}-\mathrm{CuO} / \mathrm{H}_{2} \mathrm{O}$ hybrid NF by $17.52 \%$ whereas it was enhanced by $15.72 \%$ and $15.35 \%$ with $\mathrm{Cu} / \mathrm{H}_{2} \mathrm{O}$ and $\mathrm{CuO} / \mathrm{H}_{2} \mathrm{O} \mathrm{NFs}$, respectively. Moreover, the enhancement in collector thermal efficiency was $2.175 \%, 1.05 \%$, and $0.93 \%$, the improvement in the collector exergy efficiency was $2.59 \%, 2.32 \%$ and $2.18 \%$. In contrast, the increase in the pressure drop was $2.918 \%$, $3.09 \%$, and $2.74 \%$, respectively for $\mathrm{Cu}-\mathrm{CuO} / \mathrm{H}_{2} \mathrm{O}, \mathrm{Cu} / \mathrm{H}_{2} \mathrm{O}$ and $\mathrm{CuO} / \mathrm{H}_{2} \mathrm{O}$ NFs. Tahat and Benim [60] experimentally studied the thermo-physical properties of hybrid NF contains $\mathrm{Al}_{2} \mathrm{O}_{3}-\mathrm{CuO}$ immersed in ethylene glycol and water mixture with a ratio of 25:75 (by weight) and examined its effect on the efficiency enhancement of FPSC at different concentrations $(0.5 \%, 1 \%, 1.5 \%$ and $2 \%)$. Outcomes of their study showed that viscosity and density increased as the concentration increases, and the thermal efficiency was improved by up to $95 \%$ compared with the water as a base fluid. Furthermore, the thermal efficiency was increased by $42 \%, 45 \%, 48 \%$, and $52 \%$ at concentration of $0.5 \%, 1 \%, 1.5 \%$ and $2 \%$, respectively. Verma et al. [50] experimentally investigated the effect of hybrid NFs combinations of $\mathrm{CuO}$ and $\mathrm{MgO}$ with Multi-Walled Carbon Nanotubes (MWCNTs) mixed with water base fluid. The combinations were tested for $0.25,0.5,0.75,1,1.25,1.5$ and $2 \%$ concentrations with fluid flow rate varied between 0.5 and $2 \mathrm{lpm}$ to observe the energetic and exergetic performance of FPSC. The results indicated that higher thermal performance of the collector was achieved under $\mathrm{MgO}-\mathrm{MWCNTS} \mathrm{NF}$, where the energetic and exergetic efficiencies were $71.54 \%$ and $70.55 \%$ compared to 70.63 and $69.11 \%$ for $\mathrm{CuO}-\mathrm{MWCNTS}$ NF. The enhancement of total collector efficiency gained from MgO-MWCNTs hybrid NF was higher by $25.1 \%$ and $16.28 \%$ when compared with the case of water and $\mathrm{MgO} /$ water NF, respectively. More investigations on the thermal performance of NFs employed for FPSCs are summarized in Table 2 [61-77].
It is worth mentioning that there are several studies reporting improvements in solar systems driven by FPSCs based NFs solar systems such as solar stills, solar heating and refrigeration, solar domestic hot water, and power generation. In this regard, Table 3 [78-85] summarizes several systems and improvements.

\section{Obstacles of NFs in FPSCs}

In the studies conducted in the last few years, NFs have been proved to be an excellent potential technique for increasing the heat transfer of different applications of solar collectors $[86,87]$. Due to its low thermal efficiency and suitability for a wide range of hot-water applications, FPSC has received remarkable attention from researchers who attempted to improve its performance by NFs. Although significant improvement of the efficiency using various types of NFs has been reported, the research in this area is still ongoing day by day to optimize the heat transfer rate and reduce the limitations and obstacles for better adaptability with the lowest cost toward its commercialization. The main obstacles in applying NFs in FPSCs are addressed below.

\subsection{Instability}

Instability of NF means that NPs could not suspend in the base fluid over the service period [24]. Instability decreases the ability of fluid to transfer heat and lower its efficiency, and thus, it may eliminate the purpose of using NPs. The main reason for NF instability is the interaction between the NPs and the base fluid, or between the particles themselves [88]. NF instability caused due to two opposite forces; the well-known Van der Waals force and double-layer repulsive force. Van der Waals force attracts NPs surfaces into each other and forms the so-called cluster/ agglomerations which then separate from the base fluid and sediment due to gravitation. The other opposite force is the double layer repulsive force among NPs due to steric and electrostatic repulsion [89]. Based on those statements, the stability of NF is established when the effect of Van der Waals force is lesser than the repulsive force over the lifetime of NF operation.

Several methods are applied to make the NF stable, such as sonication, magnetic stirrer and adding of surfactants (Fig. 11), which is the most recommended method in this regard [90]. Sonication is a method that utilizes the sound energy to shake particles or intermittent fibers in a liquid. As frequency larger than $>20 \mathrm{kHz}$ is used in this method, it is also known as ultrasonication method. Sonication usually conducted by either an ultrasonic bath 


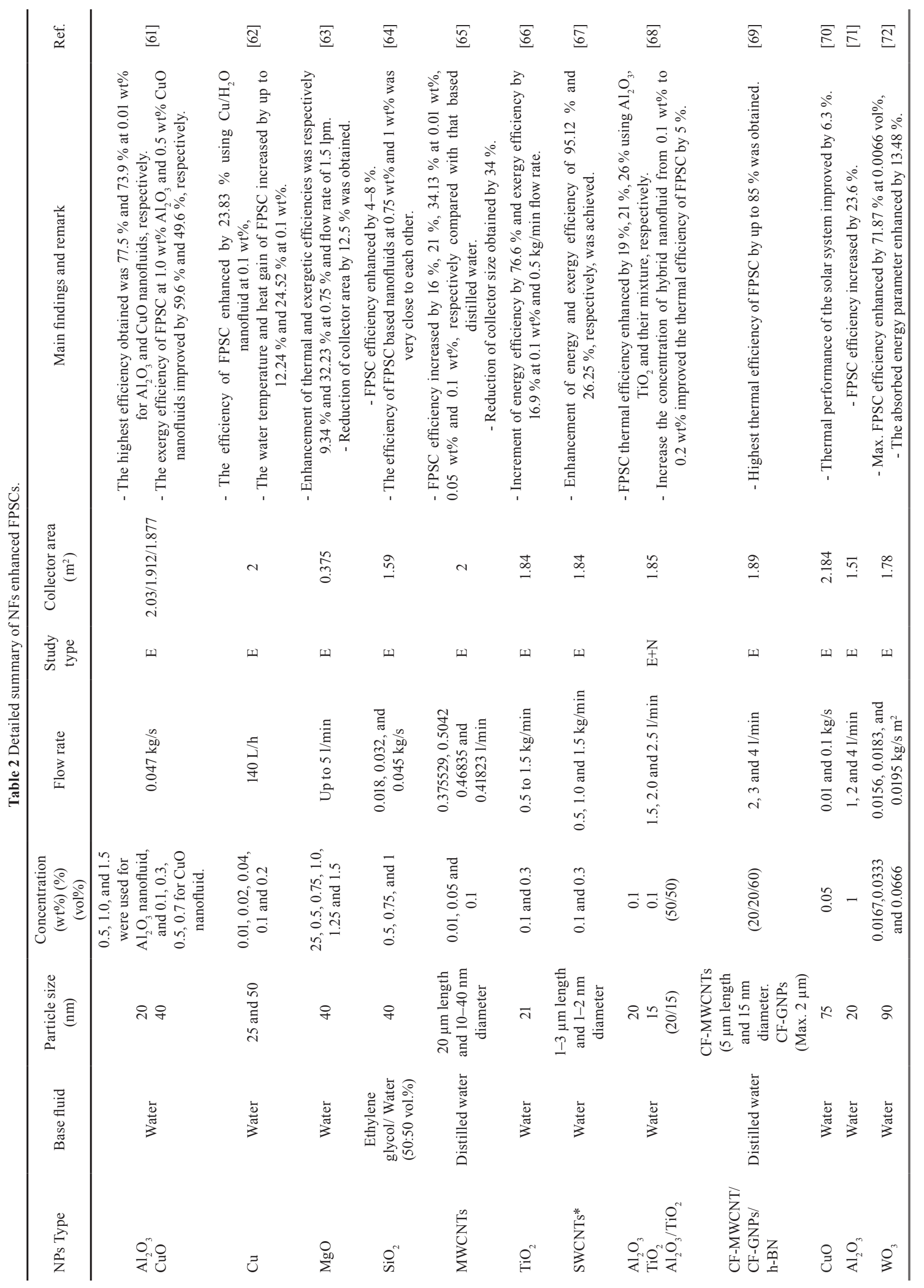




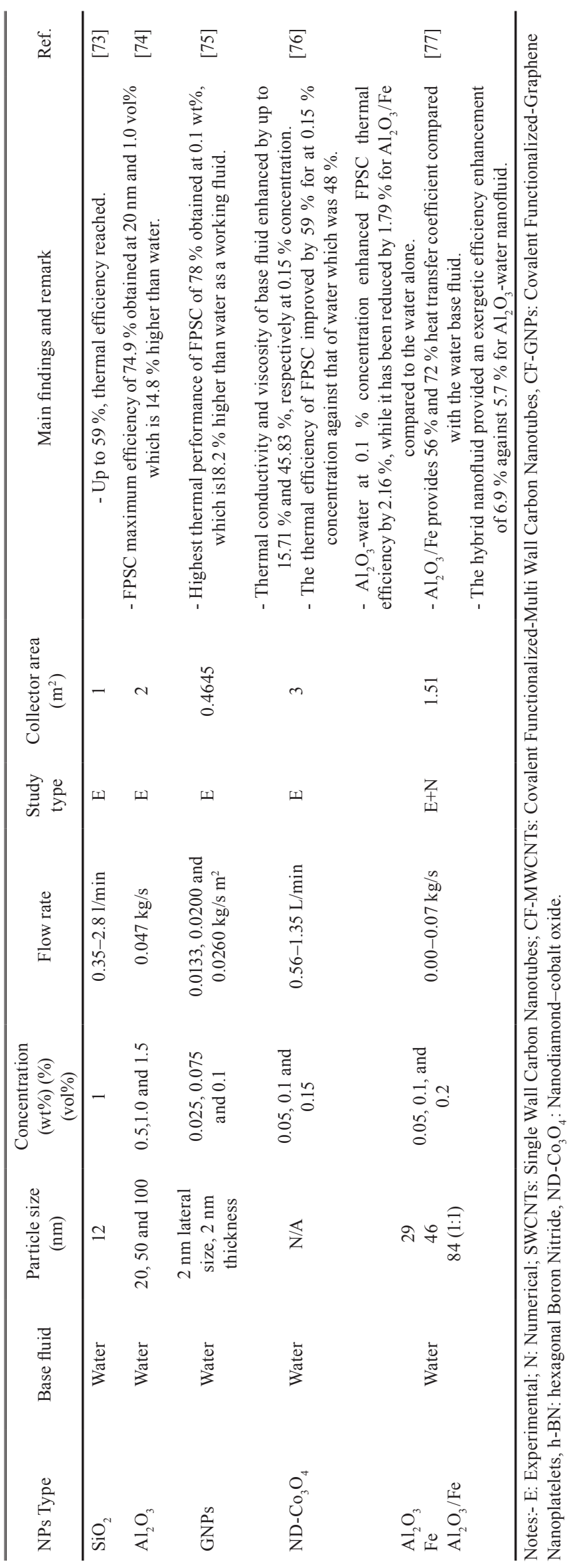


Table 3 Improvements of systems driven by FPSCs based NFs.

\begin{tabular}{|c|c|c|c|c|c|c|c|}
\hline \multirow{2}{*}{ Application } & \multirow{2}{*}{$\begin{array}{l}\text { FPSC(s) } \\
\text { Area }\left(\mathrm{m}^{2}\right)\end{array}$} & \multicolumn{3}{|c|}{$\begin{array}{c}\text { NF characteristics } \\
\text { (water is the base fluid in all cases) }\end{array}$} & \multirow{2}{*}{ Flow rate } & \multirow{2}{*}{ Main findings and remark } & \multirow{2}{*}{ Ref. } \\
\hline & & Type & $\begin{array}{l}\text { Particle } \\
\text { size }(n m)\end{array}$ & Concentration & & & \\
\hline $\begin{array}{l}\text { Solar } \\
\text { domestic hot } \\
\text { water }\end{array}$ & 1.2 & GNPs & $\begin{array}{l}2 \mu \mathrm{m} \\
\text { diameter, } \\
\text { and } 2 \mathrm{~nm} \\
\text { thickness }\end{array}$ & $\begin{array}{c}0.0005 \% \text {, } \\
0.001 \% \text { and } \\
0.005 \%\end{array}$ & $\begin{array}{l}0.0075,0.015 \\
\text { and } 0.225 \mathrm{~kg} / \mathrm{s}\end{array}$ & $\begin{array}{l}\text { - FPSC efficiency improved by } 83.54 \%, 89.71 \% \\
\text { and } 93.24 \% \text { at } 0.0005 \%, 0.001 \% \text { and } 0.005 \% \\
\text { concentration, respectively which is suitable } \\
\text { for domestic hot water applications. }\end{array}$ & [78] \\
\hline $\begin{array}{l}\text { Solar } \\
\text { distillation }\end{array}$ & 4.6 & $\begin{array}{c}\mathrm{SiO}_{2} \\
\mathrm{Cu}\end{array}$ & $\begin{array}{c}7 \\
40\end{array}$ & $\begin{array}{l}0 \%, 0.5 \% \\
1 \% \text { and } 2 \%\end{array}$ & $\begin{array}{c}5 \times 10^{-5}, \\
6.67 \times 10^{-5}, \text { and } \\
8.33 \times 10^{-5} \mathrm{~m}^{3} / \mathrm{s}\end{array}$ & $\begin{array}{l}\text { - } \mathrm{SiO}_{2} / \text { water enhanced the evaporation rate of } \\
\text { solar still at high temperatures, whereas, } \mathrm{Cu} / \text { water } \\
\text { performed better at low temperatures compared } \\
\text { with pure water-based FPSC. } \\
\text { - The best performance of FPSC based Cu/water } \\
\text { at } 4 \% \text { concentration where the yield, thermal } \\
\text { efficiency, and exergy efficiency of the solar still } \\
\text { were enhanced by } 9.86 \%, 9.91 \% \text {, and } 11.8 \% \text {, } \\
\text { respectively. }\end{array}$ & [79] \\
\hline $\begin{array}{l}\text { Absorption } \\
\text { chiller }\end{array}$ & 100 & $\mathrm{Cu}$ & 100 & $0 \%-2 \%$ & $2 \mathrm{~m}^{3} / \mathrm{s}$ & $\begin{array}{l}\text { - On a daily basis, the use of } \mathrm{Cu} / \text { water at } 2 \% \\
\text { concentration enhanced the performance of } \\
\text { FPSC. It improved the parameters of the chiller } \\
\text { as follows: collector exergetic efficiency }(2.25 \%) \text {, } \\
\text { chiller exergy efficiency }(0.62 \%) \text {, system exergy } \\
\text { efficiency }(3.99 \%) \text {, collector thermal efficiency } \\
(1.02 \%) \text {, system coefficient of performance (COP) } \\
\text { and daily cooling production }(0.84 \%) \text {. }\end{array}$ & [80] \\
\hline $\begin{array}{l}\text { Hot water } \\
\text { solar energy } \\
\text { system }\end{array}$ & 2 & $\begin{array}{c}\mathrm{Al}_{2} \mathrm{O}_{3} \mathrm{CuO} \\
\mathrm{TiO}_{2}\end{array}$ & $\begin{array}{l}<50 \\
<50 \\
<25\end{array}$ & $\begin{array}{c}0.2 \%, 0.4 \% \\
\text { and } 0.8 \%\end{array}$ & $250 \mathrm{l} / \mathrm{h}$ & $\begin{array}{l}\text { - The highest increase in the system efficiency was } \\
\text { achieved by } \mathrm{CuO} / \text { water, whereas the lowest was } \\
\text { obtained by } \mathrm{TiO}_{2} / \text { water. } \\
\text { - At } 0.2 \% \text { particle concentration, the maximum } \\
\text { efficiency obtained was } 71 \%, 87.8 \% \text {, and } 52.5 \% \\
\text { for } \mathrm{Al}_{2} \mathrm{O}_{3} / \text { water, } \mathrm{CuO} / \text { water and } \mathrm{TiO}_{2} \text {, respectively. }\end{array}$ & [81] \\
\hline $\begin{array}{l}\text { Combined } \\
\text { Cooling, } \\
\text { Heating } \\
\text { and Power } \\
\text { (CCHP) } \\
\text { system }\end{array}$ & 395 & $\mathrm{CuO}$ & N/A & $0.00 \%-0.02 \%$ & N/A & $\begin{array}{l}\text { - The maximum daily thermal efficiency of CCHP } \\
\text { system improved by } 38.61 \% \text { and exergy efficiency } \\
\text { improved by } 17.03 \% \text {, compared with the water as } \\
\text { a working fluid. }\end{array}$ & [82] \\
\hline $\begin{array}{l}\text { Solar } \\
\text { heating } \\
\text { system }\end{array}$ & 2 & $\mathrm{CuO}$ & 25 & $\begin{array}{l}0.1 \%, 0.5 \% \\
1 \%, 1.5 \% \\
2 \%, 2.5 \% \\
3 \% \text { and } 3.5 \%\end{array}$ & $0-0.02 \mathrm{~kg} / \mathrm{m}^{2}$ & $\begin{array}{l}\text { - The increase of NF concentration up to } 2 \% \\
\text { increased the efficiency of the solar collector } \\
\text { by } 5 \% \text { compared to the collector based water. } \\
\text { Therefore, the efficiency of solar heating systems } \\
\text { was improved using NFs. }\end{array}$ & [83] \\
\hline $\begin{array}{l}\text { Solar } \\
\text { absorption } \\
\text { refrigeration } \\
\text { cycle }\end{array}$ & 325 & $\begin{array}{l}\mathrm{CuO} \\
\mathrm{Al}_{2} \mathrm{O}_{3}\end{array}$ & N/A & $0 \%-5 \%$ & $\mathrm{~N} / \mathrm{A}$ & $\begin{array}{l}\text { - The COP of solar cycle was increased by } 17.98 \% \\
\text { and } 14.51 \% \text { using } \mathrm{CuO} \text { and } \mathrm{Al}_{2} \mathrm{O}_{3} \text { respectively, at } \\
5 \% \text { concentration. } \\
\text { - The total product cost rate decreased by } 10.4 \% \\
\text { and } 5.35 \% \text { using } \mathrm{CuO} \text { and } \mathrm{Al}_{2} \mathrm{O}_{3} \text { nanofluids with } \\
5 \% \text { concentration. } \\
\text { - } \mathrm{CuO} \text { nanofluid was more preferred in terms of } \\
\text { decreasing the exergy-based cost of cooling. }\end{array}$ & [84] \\
\hline $\begin{array}{l}\text { Solar } \\
\text { desalination }\end{array}$ & N/A & $\mathrm{CuO}$ & N/A & $0.05 \%$ & N/A & $\begin{array}{c}\text { - The maximum mass of steam produced from the } \\
\text { solar distiller was } 71.72 \mathrm{~kg} \text {. } \\
\text { - } \mathrm{CuO} / \text { Water increased the volumetric efficiency } \\
\text { by } 66.23 \% \text { against } 58.36 \% \text { for the system without } \\
\mathrm{NF} \text {. }\end{array}$ & [85] \\
\hline
\end{tabular}

or probe (Fig. 11). This method is often used for dispersing NPs into base fluids, de-agglomeration of NPs, reducing the particle size, synthesis of particles and precipitation [91]. The main limitation of the sonication method is that optimal sonication time is not determined [92]. Furthermore, the stability of NF influences when the sonication time exceed the optimal sonication time [93]. A magnetic stirrer is another effective method for stable nanofluid preparation by increasing its homogeneity and decrease the sedimentation. As shown in Fig. 11, there are two knops 


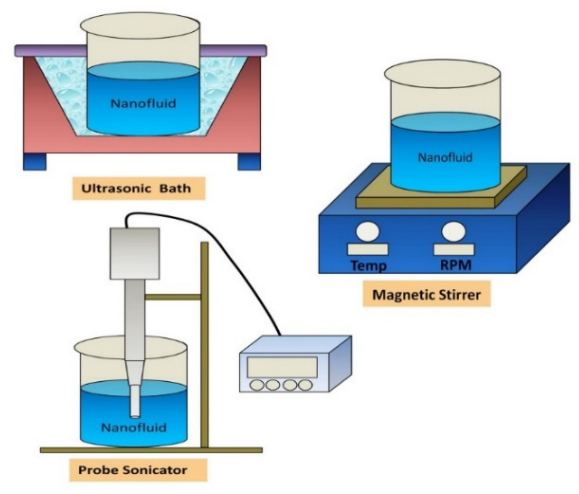

Fig. 11 Sonication and magnetic stirring methods [95].

in the magnetic stirrer; one for stirring speed rate and the other for heating. The magnetic stirring speed has to be optimized to avoid the formation of bubble throughout the preparation of NF [94]. Nevertheless, this method cannot keep NF stable for a long time and not effective at high concentrations of NPs [95]. Therefore, sonication is often used after magnetic stirring [96]. Surfactants are a simple method, and effective chemical method applies to reduce the surface tension of the base fluid and improve the immersion of NPs for long term stability [97]. Surfactants are generally divided into four categories based on head composition; namely ionic (long-chain fatty acids, alkyl sulphates, sulfosuccinates, phosphates, and sulfonates), nonionic (polyethylene oxide, alcohols), cationic (longchain quaternary ammonium compounds and long-chain amines), and amphoteric surfactants [98]. The quantity of surfactant added should be appropriately studied because the thermal conductivity of NF will decrease when the proper surfactant amount is excessed [92].

Most of the researchers indicated that instability increased as the concentration of NPs in the base fluid increased; hence the search for NFs of high thermal performance with lowest concentrations is required [99]. To evaluate the instability of NF, several methods can be applied, as shown in Fig. 12.

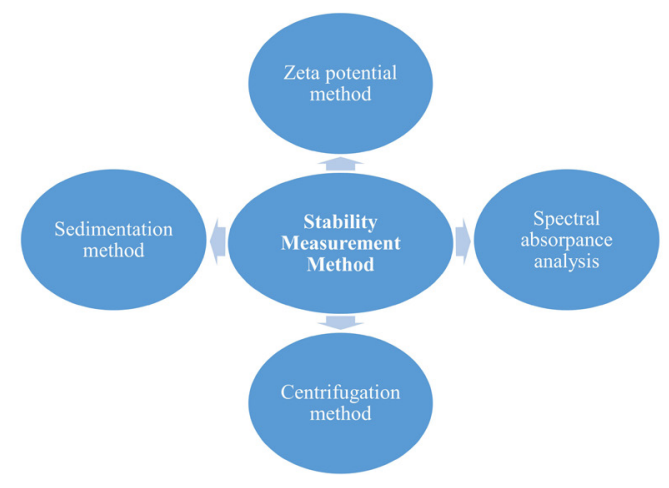

Fig. 12 Stability evaluation methods [33].

\subsection{Viscosity increment}

Fluid viscosity is the other issue facing the applicability of NFs in FPSC applications. Addition of NPs to the base fluid increases the viscosity of NF compared with the base fluid, which causes a higher pressure drop in pumping power. Therefore, the efficiency of the solar collector will be minimized eventually. Although most of the research work dealt with the effect of NPs concentration on fluid viscosity, there is lack of investigations in the other related effect factors such as the type of base fluid, application temperature limit, the size and shape of NPs [100]. Practically, in better use of NFs in thermal applications, there is a trade-off between the augmentation in thermal conductivity and increase in viscosity, taking into account the type of NPs, concentration/volume fraction, fluid temperature, shape, and size of NPs [101].

\subsection{Concentration limit}

Numerous literature studies revealed that the higher concentration of NPs the more enhancement of FPSC thermal efficiency. However, some studies reported that this enhancement has a limit. Yousefi et al. [102] found that the efficiency of FPSC at $0.2 \%$ concentration of carbon nanotube-water NF is lower than the efficiency of the case where water was used alone as the base fluid. They also stated that the FPSC efficiency was significantly increased back at $0.4 \%$ concentration. He et al. [62] reported that the efficiency of FPSC based $\mathrm{Cu}-\mathrm{H}_{2} \mathrm{O}$ nanofluids of $25 \mathrm{~nm}$ particle size at $0.2 \mathrm{wt} \%$ was lower than that of $\mathrm{Cu}-\mathrm{H}_{2} \mathrm{O}$ nanofluids at $0.1 \mathrm{wt} \%$ under the same particle size. Okonkwo et al. [77] indicated that the $\mathrm{Al}_{2} \mathrm{O}_{3}-\mathrm{Fe} /$ water hybrid NF decreased the thermal performance of FPSC by $1.79 \%$ compared to the case of the water-based fluid. These inconsistent results call the attention of researchers to conduct more investigation in this field and imply that an optimal limit of concentration exists for each NF type.

\subsection{Corrosion effect}

Few authors investigated the effect of NPs corrosion on the surfaces where the NFs flow. Study of this feature is necessary as it could limit the applicability of NFs instead of traditional ones. Fotowat et al. [103] studied the effect of three NPs (aluminum, copper, and stainless steel) mixed with water base fluid on the metallic surfaces. They concluded that the copper particles possessed the highest corrosion rate; whereas stainless steel particles showed the lowest. Prajitno and Syarif [104] investigated the corrosion effect of $\mathrm{ZrO}_{3}$ based NF on carbon steel under various temperatures ranged from 25 to $55{ }^{\circ} \mathrm{C}$. The study concluded 
that the corrosion rate gets faster as the temperature of NF increased. Several researchers such as [105] and [106] proposed successful additives and techniques that should adopt NFs in specific material surfaces. However, more research on the effect of corrosion of NPs in FPSCs applications is still in need.

\subsection{Others}

Several researchers reported other obstacles in the way of NFs practical adoption. The design of collector of heat exchanger pipes can affect the performance of NF by influencing fluid flow velocity as well as its thermal behaviour [107]. Colangelo et al. [108] revealed that flow velocity is the main factor affecting the sedimentation of NPs due to the poor design of standard FPSC heat exchanger. They fabricated a new collector prototype considering the change in the cross-section of the lower and top header in a way to keep the fluid axial velocity constant. This technique guaranteed no sedimentation of the tested $\mathrm{NF}$ (i.e. $\mathrm{Al}_{2} \mathrm{O}_{3}$-water) over working time. It is also worth mentioning that the NPs are usually expensive either due to material itself (Ag for example), or the complicated manufacturing procedure. Therefore, it can be accounted for as another important obstacle for different solar thermal applications especially for those requiring large amount of working fluid [109, 110].

\section{Conclusions and future recommendations}

Applications of nanofluids in FPSCs to enhance the overall thermal performance are reviewed in this paper. A general overview of nanofluids, classification and preparation methods are briefly presented, and their thermal performance on FPSCs are discussed and analyzed. Further, the main obstacles to their applicability and commercialization are highlighted. Based on the reviewed experimental studies, several conclusions and recommendations for future work can be made as follows:

\section{References}

[1] Greco, A., Gundabattini, E., Gnanaraj, D. S., Masselli, C. "A Comparative Study on the Performances of Flat Plate and Evacuated Tube Collectors Deployable in Domestic Solar Water Heating Systems in Different Climate Areas", Climate, 8(6), Article Number: 78, 2020.

https://doi.org/10.3390/cli8060078
- Most of the studies reported that the efficiency of FPSC incorporating NFs improved significantly over those utilizing the traditional working fluids. The improvement mainly was associated with NPs concentration, where the higher concentration resulted in higher thermal performance. However, such benefit increases the operational cost and fluid instability as well. Seeking for new types of NFs that offer an acceptable improvement in solar collector performance at lower cost and concentration is recommended.

- Hybrid NPs showed higher enhancement in the thermal efficiency than single NPs in most cases. Unfortunately, limited studies have been conducted to investigate the potential of hybrid NFs for enhancing FPSC thermal performance, and most of them were at the laboratory level. Although most of the reviewed studies were experimental, more practical studies dealing with new mixture types at different concentrations and base fluids are needed to determine the feasibility of this technology [110].

- Generally, $\mathrm{Al}_{2} \mathrm{O}_{3}$ nanoparticles are the most widespread NP type among the performed experimental studies, and the water is extensively used as a base fluid with different NP types. More research is needed to investigate the behaviour of new nanoparticles and base fluids.

- All in all, NF instability still represents a significant challenge as most of the stability enhancement studies reported the instability during their experiments [111]. Therefore, more extended stability studies are still in need for technology commercialization.

- The economic and environmental influences of using such fluids in FPSCs are still out of view [112]; therefore, more study considering techno-economic and environmental analysis is necessary to assess their viability in such applications.

[2] Al-Yasiri, Q., Szabó, M. "Solar absorption cooling systems versus traditional air-conditioning in hot climate", Research \& Development: Mechanical Engineering Letters, Szent István University, 14, pp. 9-16, 2016. [online] Available at: https://www.gek.szie.hu/ english/sites/default/files/MechanicalEngineeringLetters_2016_14. pdf [Accessed: 06 October 2020] 
[3] Al-Yasiri, Q., Szabó, M. "Consumption profile based analysis of solar thermal system for DHW in buildings", Hungarian Agricultural Engineering, 36, pp. 29-37, 2019.

https://doi.org/10.17676/HAE.2019.36.29

[4] Florschuetz, L. W. "Extension of the Hottel-Whillier model to the analysis of combined photovoltaic/thermal flat plate collectors", Solar Energy, 22(4), pp. 361-366, 1979.

https://doi.org/10.1016/0038-092X(79)90190-7

[5] Vettrivel, H., Mathiazhagan, P. "Comparison Study of Solar Flat Plate Collector with Single and Double Glazing Systems", International Journal of Renewable Energy Research, 7(1), pp. 266-274, 2017. [online] Available at: https://www.ijrernet.ijrer.org/index.php/ijrer/article/view/5397/pdf [Accessed: 06 October 2020]

[6] Bhowmik, H., Amin, R. "Efficiency improvement of flat plate solar collector using reflector", Energy Reports, 3, pp. 119-123, 2017. https://doi.org/10.1016/j.egyr.2017.08.002

[7] Sakhaei, S. A., Valipour, M. S. "Investigation on the effect of different coated absorber plates on the thermal efficiency of the flatplate solar collector" Journal of Thermal Analysis and Calorimetry, 140(3), pp. 1597-1610, 2020.

https://doi.org/10.1007/s10973-019-09148-x

[8] Kim, S., Jeong, H., Park, J. Y.., Baek, S. Y., Lee, A., Choi, S. H. "Innovative flat-plate solar collector (FPC) with coloured water flowing through a transparent tube", RSC Advances, 9(42), pp. 24192-24202, 2019.

https://doi.org/10.1039/C9RA03442K

[9] Fan, M., You, S., Gao, X., Zhang, H., Li, B., Zheng, W., Sun, L., Zhou, T. "A comparative study on the performance of liquid flatplate solar collector with a new V-corrugated absorber", Energy Conversion and Management, 184, pp. 235-248, 2019.

https://doi.org/10.1016/j.enconman.2019.01.044

[10] Sivakumar, P., Christraj, W., Sridharan, M., Jayamalathi, N. "Performance Improvement Study of Solar Water Heating System", ARPN Journal of Engineering and Applied Sciences, 7(1), pp. 45-49, 2012. [online] Available at: https://silo.tips/download/ performance-improvement-study-of-solar-water-heating-system [Accessed: 06 October 2020]

[11] Anirudh, K., Dhinakaran, S. "Performance improvement of a flat-plate solar collector by inserting intermittent porous blocks", Renewable Energy, 145, pp. 428-441, 2020. https://doi.org/10.1016/j.renene.2019.06.015

[12] García, A., Herrero-Martin, R., Solano, J. P., Pérez-García, J. "The role of insert devices on enhancing heat transfer in a flatplate solar water collector", Applied Thermal Engineering, 132, pp. 479-489, 2018.

https://doi.org/10.1016/j.applthermaleng.2017.12.090

[13] Scopus "Statistics of published items in Scopus database considering the keywords "nanofluids in flat plate solar collectors".", [online] Available at: https://www.scopus.com [Assessed: 18 October 2020]

[14] Maxwell, J. C. "A treatise on electricity and magnetism", Clarendon Press, London, UK, 1881.

[15] Nagarajan, P. K., Subramani, J., Suyambazhahan, S., Sathyamurthy, R. "Nanofluids for Solar Collector Applications: A Review", Energy Procedia, 61, pp. 2416-2434, 2014.

https://doi.org/10.1016/j.egypro.2014.12.017
[16] Elcioglu, E. B., Genc, A. M., Karadeniz, Z. H., Ezan, M. A., Turgut, A. "Nanofluid figure-of-merits to assess thermal efficiency of a flat plate solar collector", Energy Conversion and Management, 204, Article Number: 112292, 2020.

https://doi.org/10.1016/j.enconman.2019.112292

[17] Sahin, A. Z., Uddin, M. A., Yilbas, B. S., Al-Sharafi, A. "Performance enhancement of solar energy systems using nanofluids: An updated review", Renewable Energy, 145, pp. 1126-1148, 2020.

https://doi.org/10.1016/j.renene.2019.06.108

[18] Sajid, M. U., Ali, H. M. "Recent advances in application of nanofluids in heat transfer devices: A critical review", Renewable and Sustainable Energy Reviews, 103, pp. 556-592, 2019.

https://doi.org/10.1016/j.rser.2018.12.057

[19] Wang, Q., Wei, W., Li, D., Qi, H., Wang, F., Arıc1, M. "Experimental investigation of thermal radiative properties of $\mathrm{Al}_{2} \mathrm{O}_{3}$-paraffin nanofluid", Solar Energy, 177, pp. 420-426, 2019.

https://doi.org/10.1016/j.solener.2018.11.034

[20] Zhang, G., Wang, Z., Li, D., Wu, Y., Arıcı, M. "Seasonal thermal performance analysis of glazed window filled with paraffin including various nanoparticles", International Journal of Energy Research, 44(4), pp. 3008-3019, 2020.

https://doi.org/10.1002/er.5129

[21] Qi, H., Deng, J., Li, D., Wang, F., Arıc1, M., Wang, Q. "Optical properties of paraffin suspension containing $\mathrm{TiO}_{2}$ nanoparticles", Optik, 208, Article Number: 164082, 2020. https://doi.org/10.1016/j.ijleo.2019.164082

[22] Uddin, M., Al Kalbani, K. S., Rahman, M. M., Alam, M. S., Al-Salti, N., Eltayeb, I. "Fundamentals of nanofluids: evolution, applications and new theory", International Journal of Biomathematics and Systems Biology, 2(1), pp. 1-32, 2016.

[23] Wen, D., Lin, G., Vafaei, S., Zhang, K. "Review of nanofluids for heat transfer applications", Particuology, 7(2), pp. 141-150, 2009. https://doi.org/10.1016/j.partic.2009.01.007

[24] Sajid, M. H., Said, Z., Saidur, R., Adikan, F. R. M., Sabri, M. F. M., Rahim, N. A. "A time variant investigation on optical properties of water based $\mathrm{Al}_{2} \mathrm{O}_{3}$ nanofluid", International Communications in Heat and Mass Transfer, 50, pp. 108-116, 2014. https://doi.org/10.1016/j.icheatmasstransfer.2013.10.006

[25] Jana, S., Salehi-Khojin, A., Zhong, W. H. "Enhancement of fluid thermal conductivity by the addition of single and hybrid nano-additives", Thermochimica Acta, 462(1-2), pp. 45-55, 2007. https://doi.org/10.1016/j.tca.2007.06.009

[26] Jama, M., Singh, T., Gamaleldin, S. M., Koc, M., Samara, A., Isaifan, R. J., Atieh, M. A. "Critical Review on Nanofluids: Preparation, Characterization, and Applications", Journal of Nanomaterials, 2016, Article ID: 6717624, 2016. https://doi.org/10.1155/2016/6717624

[27] Dhinesh Kumar, D., Valan Arasu, A. "A comprehensive review of preparation, characterization, properties and stability of hybrid nanofluids", Renewable and Sustainable Energy Reviews, 81(2), pp. 1669-1689, 2018. https://doi.org/10.1016/j.rser.2017.05.257

[28] Sidik, N. A. C., Adamu, I. M., Jamil, M. M. "Preparation Methods and Thermal Performance of Hybrid Nanofluids", Journal of Advanced Research in Applied Mechanics, 66(1), pp. 7-16, 2020. https://doi.org/10.37934/aram.66.1.716 
[29] Ramadhan, A. I., Azmi, W. H., Mamat, R., Hamid, K. A., Norsakinah, S. "Investigation on stability of tri-hybrid nanofluids in water-ethylene glycol mixture", IOP Conference Series: Materials Science and Engineering, 469, Article Number: 012068, 2019. https://doi.org/10.1088/1757-899X/469/1/012068

[30] Sidik, N. A. C., Mohammed, H. A., Alawi, O A., Samion, S. "A review on preparation methods and challenges of nanofluids", International Communications in Heat and Mass Transfer, 54, pp. 115-125, 2014.

https://doi.org/10.1016/j.icheatmasstransfer.2014.03.002

[31] Raj, P., Subudhi, S. "A review of studies using nanofluids in flat-plate and direct absorption solar collectors", Renewable and Sustainable Energy Reviews, 84, pp. 54-74, 2018. https://doi.org/10.1016/j.rser.2017.10.012

[32] Jurčević, M., Nižetić, S., Arıcı, M., Ocłoń, P. "Comprehensive analysis of preparation strategies for phase change nanocomposites and nanofluids with brief overview of safety equipment", Journal of Cleaner Production, Article Number: 122963, 2020. https://doi.org/10.1016/j.jclepro.2020.122963

[33] Babar, H., Ali, H. M. "Towards hybrid nanofluids: Preparation, thermophysical properties, applications, and challenges", Journal of Molecular Liquids, 281, pp. 598-633, 2019. https://doi.org/10.1016/j.molliq.2019.02.102

[34] Bataineh, K. M., Abbas, M. A. "Improving the performance of solar still by using nanofluids, vacuuming, and optimal basin water thickness", Desalination and Water Treatment, 173, pp. 105-116, 2020. https://doi.org/10.5004/dwt.2020.24799

[35] Ramadass, G., Vijayalakshmi, M., Natarajan, E. "Energy Investigation in Serpentine Heat Exchanger Using Aluminum Oxide Nanofluid on Solar Photovoltaic/Thermal System", Journal of Testing and Evaluation, 48(2), pp. 1031-1054, 2020. https://doi.org/10.1520/JTE20170493

[36] Fares, M., Al-Mayyahi, M., Al-Saad, M. "Heat transfer analysis of a shell and tube heat exchanger operated with graphene nanofluids", Case Studies in Thermal Engineering, 18, Article Number: 100584, 2020.

https://doi.org/10.1016/j.csite.2020.100584

[37] Heyhat, M. M., Valizade, M., Abdolahzade, S., Maerefat, M. "Thermal efficiency enhancement of direct absorption parabolic trough solar collector (DAPTSC) by using nanofluid and metal foam", Energy, 192, Article Number: 116662, 2020. https://doi.org/10.1016/j.energy.2019.116662

[38] Sarafraz, M. M., Safaei, M. R. "Diurnal thermal evaluation of an evacuated tube solar collector (ETSC) charged with graphene nanoplatelets-methanol nano-suspension", Renewable Energy, 142, pp. 364-372, 2019. https://doi.org/10.1016/j.renene.2019.04.091

[39] Chen, G., Tang, Y., Duan, L., Tang, H., Zhong, G., Wan, Z., Zhang, S., Fu, T. "Thermal performance enhancement of microgrooved aluminum flat plate heat pipes applied in solar collectors", Renewable Energy, 146, pp. 2234-2242, 2020. https://doi.org/10.1016/j.renene.2019.08.083

[40] Nižetić, S., Jurčević, M., Arıc1, M., Arasu, A. V., Xie, G. "Nanoenhanced phase change materials and fluids in energy applications: A review", Renewable and Sustainable Energy Reviews, 129, Article Number: 109931, 2020 https://doi.org/10.1016/j.rser.2020.109931
[41] Ganvir, R. B., Walke, P. V., Kriplani, V. M. "Heat transfer characteristics in nanofluid-A review", Renewable and Sustainable Energy Reviews, 75, pp. 451-460, 2017. https://doi.org/10.1016/j.rser.2016.11.010

[42] Verma, S. K., Tiwari, A. K., Tripathi, M. "An evaluative observation on impact of optical properties of nanofluids in performance of photo-thermal concentrating systems", Solar Energy, 176, pp. 709-724, 2018. https://doi.org/10.1016/j.solener.2018.10.084

[43] Verma, S. K., Tiwari, A. K., Chauhan, D. S. "Experimental evaluation of flat plate solar collector using nanofluids", Energy Conversion and Management, 134, pp. 103-115, 2017. https://doi.org/10.1016/j.enconman.2016.12.037

[44] Hemmat Esfe, M., Esfandeh, S., Saedodin, S., Rostamian, H. "Experimental evaluation, sensitivity analyzation and ANN modeling of thermal conductivity of ZnO-MWCNT/EG-water hybrid nanofluid for engineering applications", Applied Thermal Engineering, 125, pp. 673-685, 2017. https://doi.org/10.1016/j.applthermaleng.2017.06.077

[45] Farhana, K., Kadirgama, K., Rahman, M. M., Ramasamy, D., Noor, M. M., Najafi, G., Samykano, M., Mahamude, A. S. F. "Improvement in the performance of solar collectors with nanofluids-A state-of-the-art review", Nano-Structures \& NanoObjects, 18, Article Number: 100276, 2019.

https://doi.org/10.1016/j.nanoso.2019.100276

[46] Fathabadi, H. "Novel solar collector: Evaluating the impact of nanoparticles added to the collector's working fluid, heat transfer fluid temperature and flow rate", Renewable Energy, 148, pp. 1165-1173, 2020.

https://doi.org/10.1016/j.renene.2019.10.008

[47] Kamel, M. S., Al-Oran, O., Lezsovits, F. "Thermal Conductivity of $\mathrm{Al}_{2} \mathrm{O}_{3}$ and $\mathrm{CeO}_{2}$ Nanoparticles and Their Hybrid Based Water Nanofluids: An Experimental Study", Periodica Polytechnica Chemical Engineering, 2020. https://doi.org/10.3311/PPch.15382

[48] Li, D., Wu, Y., Liu, C., Zhang, G., Arıc1, M. "Energy investigation of glazed windows containing Nano-PCM in different seasons", Energy Conversion and Management, 172, pp. 119-128, 2018. https://doi.org/10.1016/j.enconman.2018.07.015

[49] Akilu, S., Baheta, A. T., Said, M. A. M., Minea, A. A., Sharma, K. V. "Properties of glycerol and ethylene glycol mixture based $\mathrm{SiO}_{2}-$ $\mathrm{CuO} / \mathrm{C}$ hybrid nanofluid for enhanced solar energy transport", Solar Energy Materials and Solar Cells, 179, pp. 118-128, 2018. https://doi.org/10.1016/j.solmat.2017.10.027

[50] Verma, S. K. Tiwari, A. K., Tiwari, S., Chauhan, D. S. "Performance analysis of hybrid nanofluids in flat plate solar collector as an advanced working fluid", Solar Energy, 167, pp. 231-241, 2018. https://doi.org/10.1016/j.solener.2018.04.017

[51] Hawwash, A. A., Rahman, A. K. A., Nada, S. A., Ookawara, S. "Numerical Investigation and Experimental Verification of Performance Enhancement of Flat Plate Solar Collector Using Nanofluids", Applied Thermal Engineering, 130, pp. 363-374, 2018. https://doi.org/10.1016/j.applthermaleng.2017.11.027

[52] Sharafeldin, M. A., Gróf, G. "Experimental investigation of flat plate solar collector using $\mathrm{CeO}_{2}$-water nanofluid", Energy Conversion and Management, 155, pp. 32-41, 2018. https://doi.org/10.1016/j.enconman.2017.10.070 
[53] Genc, A. M., Ezan, M. A., Turgut, A. "Thermal performance of a nanofluid-based flat plate solar collector: A transient numerical study", Applied Thermal Engineering, 130, pp. 395-407, 2018. https://doi.org/10.1016/j.applthermaleng.2017.10.166

[54] Kiliç, F., Menlik, T., Sözen, A. "Effect of titanium dioxide/water nanofluid use on thermal performance of the flat plate solar collector", Solar Energy, 164, pp. 101-108, 2018. https://doi.org/10.1016/j.solener.2018.02.002

[55] International Organization for Standardization "ISO 9806:2017 Solar energy - Solar thermal collectors - Test methods", International Organization for Standardization, Geneva, Switzerland, 2017.

[56] Alawi, O. A., Kamar, H. M., Mallah, A. R., Kazi, S. N., Sidik, N. A. C. "Thermal efficiency of a flat-plate solar collector filled with Pentaethylene Glycol-Treated Graphene Nanoplatelets: An experimental analysis", Solar Energy, 191, pp. 360-370, 2019. https://doi.org/10.1016/j.solener.2019.09.011

[57] Yıldız, Ç., Arıcı, M., Karabay, H. "Comparison of a theoretical and experimental thermal conductivity model on the heat transfer performance of $\mathrm{Al}_{2} \mathrm{O}_{3}-\mathrm{SiO}_{2}$ /water hybrid-nanofluid", International Journal of Heat and Mass Transfer, 140, pp. 598-605, 2019. https://doi.org/10.1016/j.ijheatmasstransfer.2019.06.028

[58] Ahmadi, M. H., Ghazvini, M., Sadeghzadeh, M., Nazari, M. A., Ghalandari, M. "Utilization of hybrid nanofluids in solar energy applications: a review", Nano-Structures \& Nano-Objects, 20, Article Number: 100386, 2019. https://doi.org/10.1016/j.nanoso.2019.100386

[59] Ranga Babu, J. A., Kiran Kumar, K., Srinivasa Rao, S. "Thermodynamic analysis of hybrid nanofluid based solar flat plate collector", World Journal of Engineering, 15(1), pp. 27-39, 2018. https://doi.org/10.1108/WJE-03-2017-0048

[60] Tahat, M. S., Benim, A. C. "Experimental Analysis on Thermophysical Properties of $\mathrm{Al}_{2} \mathrm{O}_{3} / \mathrm{CuO}$ Hybrid Nano Fluid With its Effects on Flat Plate Solar Collector", Defect and Diffusion Forum, 374, pp. 148-156, 2017.

https://doi.org/10.4028/www.scientific.net/DDF.374.148

[61] Tong, Y., Lee, H., Kang, W., Cho, H. "Energy and exergy comparison of a flat-plate solar collector using water, $\mathrm{Al}_{2} \mathrm{O}_{3}$ nanofluid, and $\mathrm{CuO}$ nanofluid", Applied Thermal Engineering, 159, Article Number: 113959, 2019. https://doi.org/10.1016/j.applthermaleng.2019.113959

[62] He, Q., Zeng, S., Wang, S. "Experimental investigation on the efficiency of flat-plate solar collectors with nanofluids", Applied Thermal Engineering, 88, pp. 165-171, 2015. https://doi.org/10.1016/j.applthermaleng.2014.09.053

[63] Verma, S. K., Tiwari, A. K., Chauhan, D. S. "Performance augmentation in flat plate solar collector using $\mathrm{MgO}$ /water nanofluid", Energy Conversion and Management, 124, pp. 607-617, 2016. https://doi.org/10.1016/j.enconman.2016.07.007

[64] Salavati Meibodi, S., Kianifar, A., Niazmand, H., Mahian, O., Wongwises, S. "Experimental investigation on the thermal efficiency and performance characteristics of a flat plate solar collector using $\mathrm{SiO}_{2}$ /EG-water nanofluids", International Communications in Heat and Mass Transfer, 65, pp. 71-75, 2015.

https://doi.org/10.1016/j.icheatmasstransfer.2015.02.011
[65] Eltaweel, M., Abdel-Rehim, A. A. "Energy and exergy analysis of a thermosiphon and forced-circulation flat-plate solar collector using MWCNT/Water nanofluid", Case Studies in Thermal Engineering, 14, Article Number: 100416, 2019.

https://doi.org/10.1016/j.csite.2019.100416

[66] Said, Z., Sabiha, M. A., Saidur, R., Hepbasli, A., Rahim, N. A., Mekhilef, S., Ward, T. A. "Performance enhancement of a Flat Plate Solar collector using Titanium dioxide nanofluid and Polyethylene Glycol dispersant", Journal of Cleaner Production, 92, pp. 343-353, 2015. https://doi.org/10.1016/j.jclepro.2015.01.007

[67] Said, Z., Saidur, R., Sabiha, M. A., Rahim, N. A., Anisur, M. R. "Thermophysical properties of Single Wall Carbon Nanotubes and its effect on exergy efficiency of a flat plate solar collector", Solar Energy, 115, pp. 757-769, 2015. https://doi.org/10.1016/j.solener.2015.02.037

[68] Farajzadeh, E., Movahed, S., Hosseini, R. "Experimental and numerical investigations on the effect of $\mathrm{Al}_{2} \mathrm{O}_{3} / \mathrm{TiO}_{2}-\mathrm{H}_{2} \mathrm{O}$ nanofluids on thermal efficiency of the flat plate solar collector", Renewable Energy, 118, pp. 122-130, 2018. https://doi.org/10.1016/j.renene.2017.10.102

[69] Hussein, O. A., Habib, K., Muhsan, A. S., Saidur, R., Alawi, O. A., Ibrahim, T. K. "Thermal performance enhancement of a flat plate solar collector using hybrid nanofluid", Solar Energy, 204, pp. 208-222, 2020.

https://doi.org/10.1016/j.solener.2020.04.034

[70] Michael, J. J., Iniyan, S. "Performance of copper oxide/water nanofluid in a flat plate solar water heater under natural and forced circulations", Energy Conversion and Management, 95, pp. $160-169,2015$

https://doi.org/10.1016/j.enconman.2015.02.017

[71] Mirzaei, M., Hosseini, S. M. S., Moradi Kashkooli, A. M. "Assessment of $\mathrm{Al}_{2} \mathrm{O}_{3}$ nanoparticles for the optimal operation of the flat plate solar collector", Applied Thermal Engineering, 134, pp. 68-77, 2018.

https://doi.org/10.1016/j.applthermaleng.2018.01.104

[72] Sharafeldin, M. A., Gróf, G., Mahian, O. "Experimental study on the performance of a flat-plate collector using $\mathrm{WO}_{3} /$ Water nanofluids", Energy, 141, pp. 2436-2444, 2017.

https://doi.org/10.1016/j.energy.2017.11.068

[73] Noghrehabadi, A., Hajidavalloo, E., Moravej, M. "Experimental investigation of efficiency of square flat-plate solar collector using $\mathrm{SiO}_{2}$ /water nanofluid", Case Studies in Thermal Engineering, 8, pp. 378-386, 2016.

https://doi.org/10.1016/j.csite.2016.08.006

[74] Kang, W., Shin, Y., Cho, H. "Economic Analysis of Flat-Plate and U-Tube Solar Collectors Using an $\mathrm{Al}_{2} \mathrm{O}_{3}$ Nanofluid", Energies, 10(11), Article Number: 1911, 2017. https://doi.org/10.3390/en10111911

[75] Akram, N., Sadri, R., Kazi, S. N., Ahmed, S. M., Zubir, M. N. M., Ridha, M., Soudagar, M., Ahmed, W., Arzpeyma, M., Tong, G. B. "An experimental investigation on the performance of a flatplate solar collector using eco-friendly treated graphene nanoplatelets-water nanofluids", Journal of Thermal Analysis and Calorimetry, 138(1), pp. 609-621, 2019. https://doi.org/10.1007/s10973-019-08153-4 
[76] Syam Sundar, L., Misganaw, A. H., Singh, M. K., Sousa, A. C. M., Ali, H. M. "Efficiency analysis of thermosyphon solar flat plate collector with low mass concentrations of $\mathrm{ND}-\mathrm{Co}_{3} \mathrm{O}_{4}$ hybrid nanofluids: an experimental study", Journal of Thermal Analysis and Calorimetry, 2020. https://doi.org/10.1007/s10973-020-10176-1

[77] Okonkwo, E. C., Wole-Osho, I., Kavaz, D., Abid, M., Al-Ansari, T. "Thermodynamic evaluation and optimization of a flat plate collector operating with alumina and iron mono and hybrid nanofluids", Sustainable Energy Technologies and Assessments, 37, Article Number: 100636, 2020. https://doi.org/10.1016/j.seta.2020.100636

[78] Vakili, M., Hosseinalipour, S. M., Delfani, S., Khosrojerdi, S., Karami, M. "Experimental investigation of graphene nanoplatelets nanofluid-based volumetric solar collector for domestic hot water systems", Solar Energy, 131, pp. 119-130, 2016

https://doi.org/10.1016/j.solener.2016.02.034

[79] Mahian, O., Kianifar, A., Heris, S. Z., Wen, D., Sahin, A. Z., Wongwises, S. "Nanofluids effects on the evaporation rate in a solar still equipped with a heat exchanger", Nano Energy, 36, pp. 134-155, 2017.

https://doi.org/10.1016/j.nanoen.2017.04.025

[80] Bellos, E., Tzivanidis, C. "Performance analysis and optimization of an absorption chiller driven by nanofluid based solar flat plate collector", Journal of Cleaner Production, 174, pp. 256-272, 2018. https://doi.org/10.1016/j.jclepro.2017.10.313

[81] Ziyadanogullari, N. B., Yucel, H. L., Yildiz, C. "Thermal performance enhancement of flat-plate solar collectors by means of three different nanofluids", Thermal Science and Engineering Progress, 8, pp. 55-65, 2018

https://doi.org/10.1016/j.tsep.2018.07.005

[82] Boyaghchi, F. A., Montazerinejad, H. "Multi-objective optimisation of a novel combined cooling, heating and power system integrated with flat plate solar collectors using water/CuO nanofluid", International Journal of Exergy(IJEX), 21(2), pp. 202-238, 2016. https://doi.org/10.1504/IJEX.2016.078926

[83] Sint, N. K. C., Choudhury, I. A., Masjuki, H. H., Aoyama, H. "Theoretical analysis to determine the efficiency of a $\mathrm{CuO}$-water nanofluid based-flat plate solar collector for domestic solar water heating system in Myanmar", Solar Energy, 155, pp. 608-619, 2017. https://doi.org/10.1016/j.solener.2017.06.055

[84] Asgharian, H., Baniasadi, E., Ozgur Colpan, C. "Energy, exergy and exergoeconomic analyses of a solar refrigeration cycle using nanofluid", International Journal of Exergy(IJEX), 30(1), pp. 63-85, 2019. https://doi.org/10.1504/IJEX.2019.101625

[85] Azarudeen, M. M., Muralidharan, K., Prakash, P. R., Rajasekar, R., Kumar, R. N. "Experimental Investigation of the Thermo-Physical Properties of Nanofluids (CuO) and its Effect on a Flat Plate Solar Collector for Desalination Process", Research and Applications of Thermal Engineering, 2(1), Article Number: 690, 2019. [online] Available at: http:/hbrppublication.com/OJS/index.php/RATE/ article/view/690 [Accessed: 06 October 2020]
[86] Shah, J., Gupta, S. K., Sonvane, Y., Davariya, V. "Review: Enhancing efficiency of solar thermal engineering systems by thermophysical properties of a promising nanofluids", Renewable and Sustainable Energy Reviews, 77, pp. 1343-1348, 2017. https://doi.org/10.1016/j.rser.2017.02.030

[87] Maouassi, A., Baghidja, A., Douad, S., Zeraibi, N. "Heat Exchanges Intensification through a Flat Plat Solar Collector by using Nanofluids as Working Fluid", Frontiers in Heat and Mass Transfer(FHMT), 10, Article Number: 35, 2018. https://doi.org/10.5098/hmt.10.35

[88] Dey, D., Kumar, P., Samantaray, S. "A review of nanofluid preparation, stability, and thermo-physical properties", Heat Transfer, 46(8), pp. 1413-1442, 2017.

https://doi.org/10.1002/htj.21282

[89] Arthur, O., Karim, M. A. "An investigation into the thermophysical and rheological properties of nanofluids for solar thermal applications", Renewable and Sustainable Energy Reviews, 55, pp. 739-755, 2016.

https://doi.org/10.1016/j.rser.2015.10.065

[90] Almanassra, I. W., Manasrah, A. D., Al-Mubaiyedh, U. A., Al-Ansari, T., Malaibari, Z. O., Atieh, M. A. "An experimental study on stability and thermal conductivity of water/CNTs nanofluids using different surfactants: A comparison study", Journal of Molecular Liquids, 304, Article Number: 111025, 2020. https://doi.org/10.1016/j.molliq.2019.111025

[91] Asadi, A., Alarifi, I. M. "Effects of ultrasonication time on stability, dynamic viscosity, and pumping power management of MWCNT-water nanofluid: an experimental study", Scientific Reports, 10(1), Article Number: 15182, 2020. https://doi.org/10.1038/s41598-020-71978-9

[92] Ali, A. R. I., Salam, B. "A review on nanofluid: preparation, stability, thermophysical properties, heat transfer characteristics and application", SN Applied Sciences, 2(10), Article Number: 1636, 2020. https://doi.org/10.1007/s42452-020-03427-1

[93] Afzal, A., Nawfal, I., Mahbubul, I. M., Kumbar, S. S. "An overview on the effect of ultrasonication duration on different properties of nanofluids", Journal of Thermal Analysis and Calorimetry, 135(1), pp. 393-418, 2019. https://doi.org/10.1007/s10973-018-7144-8

[94] Mukherjee, S., Mishra, P. C., Chaudhuri, P. "Stability of Heat Transfer Nanofluids - A Review", ChemBioEng Reviews, 5(5), pp. 312-333, 2018. https://doi.org/10.1002/cben.201800008

[95] Chakraborty, S., Panigrahi, P. K. "Stability of nanofluid: A review", Applied Thermal Engineering, 174, Article Number: 115259, 2020. https://doi.org/10.1016/j.applthermaleng.2020.115259

[96] Chakraborty, S., Sarkar, I., Behera, D. K., Pal, S. K., Chakraborty, S. "Experimental investigation on the effect of dispersant addition on thermal and rheological characteristics of $\mathrm{TiO}_{2}$ nanofluid", Powder Technology, 307, pp. 10-24, 2017. https://doi.org/10.1016/j.powtec.2016.11.016 
[97] Askar, A. H., Kadham, S. A., Mshehid, S. H. "The surfactants effect on the heat transfer enhancement and stability of nanofluid at constant wall temperature", Heliyon, 6(7), Article Number: E04419, 2020.

https://doi.org/10.1016/j.heliyon.2020.e04419

[98] Ali, N., Teixeira, J. A., Addali, A. "A Review on Nanofluids: Fabrication, Stability, and Thermophysical Properties", Journal of Nanomaterials, 2018, Article ID: 6978130, 2018. https://doi.org/10.1155/2018/6978130

[99] Raja, M., Vijayan, R., Dineshkumar, P., Venkatesan, M. "Review on nanofluids characterization, heat transfer characteristics and applications", Renewable and Sustainable Energy Reviews, 64, pp. 163-173, 2016.

https://doi.org/10.1016/j.rser.2016.05.079

[100] Murshed, S. M. S., Estellé, P. "A state of the art review on viscosity of nanofluids", Renewable and Sustainable Energy Reviews, 76, pp. 1134-1152, 2017.

https://doi.org/10.1016/j.rser.2017.03.113

[101] Maré, T., Halelfadl, S.. Van Vaerenbergh, S., Estellé, P. "Unexpected sharp peak in thermal conductivity of carbon nanotubes water-based nanofluids", International Communications in Heat and Mass Transfer, 66, pp. 80-83, 2015. https://doi.org/10.1016/j.icheatmasstransfer.2015.05.013

[102] Yousefi, T., Veisy, F., Shojaeizadeh, E., Zinadini, S. "An experimental investigation on the effect of MWCNT- $\mathrm{H}_{2} \mathrm{O}$ nanofluid on the efficiency of flat-plate solar collectors", Experimental Thermal and Fluid Science, 39, pp. 207-212, 2012. https://doi.org/10.1016/j.expthermflusci.2012.01.025

[103] Fotowat, S., Askar, S., Ismail, M., Fartaj, A. "A study on corrosion effects of a water based nanofluid for enhanced thermal energy applications", Sustainable Energy Technologies and Assessments, 24, pp. 39-44, 2017. https://doi.org/10.1016/j.seta.2017.02.001

[104] Prajitno, D. H., Syarif, D. G. "Corrosion of Carbon Steel in

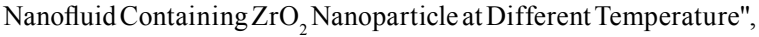
Advanced Materials Research, 896, pp. 168-172, 2014. https://doi.org/10.4028/www.scientific.net/AMR.896.168

[105] Xie, S., Zhang, Y., Song, Y., Ge, F., Huang, X., Ge, H., Zhao, Y. "Comparison of the Corrosion Behavior of Brass in $\mathrm{TiO}_{2}$ and $\mathrm{Al}_{2} \mathrm{O}_{3}$ Nanofluids", Nanomaterials, 10(6), Article Number: 1046, 2020. https://doi.org/10.3390/nano10061046
[106] Moorthy, C. V. K. N. S. N., Srinivas, V. "Corrosion and Heat Transfer Characteristics of Water Dispersed with Carboxylate Additives and Multi Walled Carbon Nano Tubes", Journal of The Institution of Engineers (India): Series C, 97(4), pp. 569-577, 2016. https://doi.org/10.1007/s40032-016-0223-3

[107] Saffarian, M. R., Moravej, M., Doranehgard, M. H. "Heat transfer enhancement in a flat plate solar collector with different flow path shapes using nanofluid", Renewable Energy, 146, pp. 2316-2329, 2020. https://doi.org/10.1016/j.renene.2019.08.081

[108] Colangelo, G., Favale, E., Miglietta, P., de Risi, A., Milanese, M., Laforgia, D. "Experimental test of an innovative high concentration nanofluid solar collector", Applied Energy, 154, pp. 874-881, 2015. https://doi.org/10.1016/j.apenergy.2015.05.031

[109] Gómez-Villarejo, R., Martín, E. I., Navas, J., SánchezCoronilla, A., Aguilar, T., Gallardo, J. J., Alcántara, R., De los Santos, D., Carrillo-Berdugo, I., Fernández-Lorenzo, C. "Ag-based nanofluidic system to enhance heat transfer fluids for concentrating solar power: Nano-level insights", Applied Energy, 194, pp. 19-29, 2017. https://doi.org/10.1016/j.apenergy.2017.03.003

[110] Shah, aT. R., Ali, H. M. "Applications of hybrid nanofluids in solar energy, practical limitations and challenges: A critical review", Solar Energy, 183, pp. 173-203, 2019. https://doi.org/10.1016/j.solener.2019.03.012

[111] Sezer, N., Atieh, M. A., Koç, M. "A comprehensive review on synthesis, stability, thermophysical properties, and characterization of nanofluids", Powder Technology, 344, pp. 404-431, 2019. https://doi.org/10.1016/j.powtec.2018.12.016

[112] Zayed, M. E., Zhao, J., Du, Y., Kabeel, A. E., Shalaby, S. M. "Factors affecting the thermal performance of the flat plate solar collector using nanofluids: A review", Solar Energy, 182, pp. 382-396, 2019. https://doi.org/10.1016/j.solener.2019.02.054 